\title{
Effectiveness of Application of Thematic Learning on Low Classes in Madrasah State Admission
}

\author{
Nunu Mahnun ${ }^{1}$, Zaitun $^{2}$, Zarkasih $^{3}$, Yulia Novita $^{4}$, Hasbullah $^{5}$ \\ Universitas Islam Negeri Sultan Syarif Kasim Riau, Pekanbaru, Indonesia $1,2,3,4,5$ \\ \{nunu.mahnun@uin-suska.ac.id $\left.{ }^{1}\right\}$
}

\begin{abstract}
This study aims to determine how effective the application of thematic learning in Madrasah Ibtidaiyah Negeri Pekanbaru. This research method is a quantitative method with a descriptive approach. The results showed that the effectiveness of the application of thematic learning in the Madrasah Ibtidaiyah Negeri Pekan Baru was very active with a percentage of $84.1 \%$. Representation of indicators: 1) Making RPP according to the steps of thematic learning, 2) Non-authoritarian teachers, 3) Teachers can foster student activity, 4) Apply the principle of education while playing, 5) Learning through direct experience, 6) Separation of subjects, 7) Use of learning media, 8) Utilize the time and energy appropriately, 8) Achieve high quality results.
\end{abstract}

Keywords: Thematic Learning, Madrasah Ibtidaiyah, Teachers

\section{Introduction}

The application of thematic learning in the teaching and learning process should improve the quality of learning methods and results, but the reality in the field still found some fundamental phenomena, which again raise doubts about the application of thematic learning models in the teaching and learning process in the classroom. The weakness of the effectiveness of the use of thematic learning, based on information, and among them can be seen from several symptoms including the discovery of children who are still lacking in absorbing the subject matter, so they must be supported by taking lessons or private, even found children who are less motivated in learning, still the lack of student activity in education and the lack of understanding between the cluster teachers who teach in the low class about operational steps in thematic education that are in line with the demands of the curriculum.

The effectiveness of learning is learning that allows students to learn specific skills, knowledge, and attitudes and which makes students happy.[1]While the characteristics of Effective Learning as stated by Eggen and Kauchak mention the characteristics of effective learning as follows: 1) Students actively interact with their environment through observing, comparing, finding similarities and differences and forming concepts of generalization based on similarity - similarities found, 2) The teacher directs students to focus on thinking and interacting in lessons, 3) Activities are fully based on assessment, 4) Teachers are actively involved in giving direction and guidance in analyzing information, 5) Learning orientation is mastering the content of the lesson and development of thinking skills, 6) Teachers use learning techniques that vary according to the goals and learning style of the teacher[1]. 
The implementation of thematic learning is based on the following practical basis: 1) The development of science is so fast, 2) Almost all lessons in schools are given separately from each other, whereas they should be interrelated, 3) Problems that arise in current learning tend to be more cross-eye lessons (interdisciplinary) so that collaborative effort is needed between various subjects, 4) The gap between theory and practice can be narrowed down with integrated learning so students will be able to think theoretically and at the same time be able to think practically[2]In thematic learning competencies, indicators and material content of several subjects are bound or combined through a specified theme. Thematic learning as a concept can be interpreted as a learning approach that involves several subjects to provide a rich experience to students. It is said to be meaningful because in this thematic learning, students will understand the concepts they learn through direct experience and relate them to other concepts they already understand.[2]Thematic learning contains two indicators, namely the occurrence of learning in students and what the teacher does[1]. Thematic Learning as a learning model is one of the types/types of integrated learning models. The term thematic learning is basically an integrated learning model that uses themes to link several subjects so that they can provide meaningful experiences for students[3].

There are several principles that need to be considered in the implementation of thematic learning in SD / MI, especially when exploring themes, implementing learning, and conducting assessments. In the process of extracting themes, the following principles must be considered.[4](1) student-centered, (2) providing direct experience, (3) not so clear separation of subjects, (4) presenting concepts from various subjects, (5) being flexible, (6) learning outcomes in accordance with interests and needs students, and (7) using the principle of learning while playing and fun [4]. The characteristics of thematic learning models in Primary Schools according to Team Puskur that need to be understood from thematic learning to be carried out, namely: 1) Student-centered, 2) Can provide experience directly to students (direct experiences), 3) Separation between subjects becomes less clear, 4) Presenting concepts from various subjects in a learning process, 5) Being flexible (flexible), 6) Learning outcomes can develop according to student interests and needs[4].

Some previous research related to this research is from N Sukerti revealed three points of findings in the research conducted; first Learning interest in thematic learning with conventional has a level of difference, secondly Student learning outcomes through thematic learning are higher than conventional, the three differences in learning interest and learning outcomes between students who learn through integrated thematic learning through a scientific approach with students who follow conventional learning are not significant[5]. Other researchers, K Diputra, revealed that the multimedia developed in thematic learning was well qualified. This means that the multimedia developed is ready to be used publicly in thematic learning [6]. Mulyadin revealed that the implementation of integrated thematic learning policy for the 2013 curriculum at SDN Kauman 1 Malang and SD Muhammadiyah 1 Malang had been categorized as good, this was seen from the aspects of mastery, understanding and ability of the teacher in the learning planning process, implementation of learning, and assessment of learning outcomes as well as in the process the supervision carried out by the principal had run maximally[7].

This study aims to determine how effective the application of thematic learning in Madrasah Ibtidaiyah Negeri Pekan baru. Urgency of research is done because the theory says that the effectiveness and success of the learning process is partly influenced by the learning model used in the teaching and learning process. Speaking of effectiveness is very important because effectiveness is closely related to the quality and quality of education. 


\section{Method}

After the data is collected then the data will be analyzed descriptively. Qualitative data will be described in words, while quantitative data will be represented by numbers, by finding the percentage using the formula.

$$
\mathrm{P}=\frac{F}{\mathrm{~N}} \times 100
$$

Note: $\mathrm{P}=$ Persentase, $\mathrm{F}=$ Frekuensi, $\mathrm{N}=$ Total

After being presented then the number is interpreted with qualitative sentences, the following criteria: $76 \%-100 \%=$ very effective $56 \%-75 \%=$ effective $40 \%-55 \%=$ effective enough $0 \%-39 \%=$ not effective.[8]

\section{Result and discussion}

\subsection{Teachers Make Learning Plane According to The Steps of Thematic Learning}

Table 1. Learning Implementation Plans (RPP) are Made According to The Steps of Thematic Learning

\begin{tabular}{|c|c|c|c|c|c|c|c|}
\hline \multirow[t]{3}{*}{ No } & \multirow[t]{3}{*}{ Questionnaire statement } & \multicolumn{4}{|c|}{ Answer } & \multicolumn{2}{|c|}{ Total } \\
\hline & & \multicolumn{2}{|c|}{ Yes } & \multicolumn{2}{|c|}{ No } & & \\
\hline & & $\mathbf{F}$ & $\%$ & $\mathbf{F}$ & $\%$ & $\mathbf{N}$ & $\mathbf{P}$ \\
\hline 1. & $\begin{array}{l}\text { The teacher makes lesson plans according to the } \\
\text { steps of thematic learning }\end{array}$ & 4 & 66,7 & 2 & 33,3 & 6 & $\begin{array}{c}100 \\
\%\end{array}$ \\
\hline
\end{tabular}

From the table above, four teachers $(66.7 \%)$ of the six people observed had made lesson plans by the steps of thematic learning while two teachers $(33.3 \%)$ made the lesson plan incompatible with the levels of thematic education. The incompatibility of the RPP that has been made from 2 teachers $(33.3 \%)$ who made RPP with the steps of thematic learning. This can be seen subjects only contain one question, do not include several items that are binding on one theme, material, essential competencies, and indicators in the RPP only include equipment, necessary skills, and specific indicators on just one subject. It should consist of content, essential competencies, and signs of several issues that are binding on one theme raised, steps in the core activities are not detailed in the levels of thematic learning that are made. In general, from the analysis of the last two documents in the RPP that are not by the steps of thematic learning, the RPP is more to apply the learning gems learning approach (separation of subjects) regardless of theme / without being bound by the theme.

\subsection{Teachers Are Not Authorized / Single Actors}

Table 2. Teachers Are Not Single Actor / Authoritarian in Learning

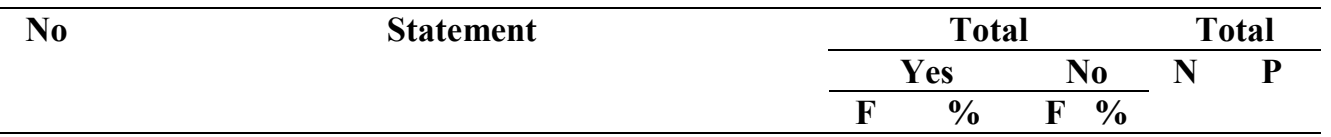




\begin{tabular}{clcccccc}
\hline 1. & The teacher wants to be debated & 6 & 100 & 0 & 0 & 6 & 100 \\
\hline 2. & Give the opportunity to ask students & 6 & 100 & 0 & 0 & 6 & 100 \\
\hline 3. & The teacher does not blame students' opinions & 6 & 100 & 0 & 0 & 6 & 100 \\
\hline & Total & 18 & 100 & 0 & 0 & 18 & 100 \\
\hline
\end{tabular}

The table above shows that; First, the teacher wants to be debated, which shows 6 of the six teachers observed or $100 \%$ of the teachers want to be discussed by their students. Both teachers gave the opportunity to ask students, showing that 6 of the six teachers were observed or $100 \%$ of teachers gave the chance to ask their students. The three teachers did not blame students 'opinions, showing that 6 out of 6 teachers were observed or $100 \%$ of teachers did not blame students' opinions. So that $100 \%$ of teachers are not authoritarian in applying thematic learning. The three indicators above, $100 \%$ (6 teachers) are not strict in thematic learning, it can be understood that according to the theory previously stated that in thematic education and active learning approaches the teacher does not dominate the class, in this case, the teacher does not make children as objects of knowledge and is authoritarian in learning, it has been applied to the schools of the Pekanbaru State Islamic Elementary School. Thus the paradigm of the Madrasah Ibtidaiyah Negeri Pekanbaru teachers towards learning has changed to a new model that adopts a student-centered learning approach.

\subsection{Teachers can Foster Student Activity}

Table 3. Teachers Able to Grow Student Activity in Learning

\begin{tabular}{|c|c|c|c|c|c|c|c|}
\hline \multirow[t]{3}{*}{ No } & \multirow[t]{3}{*}{ Statement } & \multicolumn{4}{|c|}{ Total } & \multicolumn{2}{|c|}{ Total } \\
\hline & & \multicolumn{2}{|c|}{ Yes } & \multicolumn{2}{|c|}{ No } & \multirow[t]{2}{*}{$\mathbf{N}$} & \multirow[t]{2}{*}{$\mathbf{P}$} \\
\hline & & $\mathbf{F}$ & $\%$ & $\mathbf{F}$ & $\%$ & & \\
\hline 1. & Grow students' activeness to ask & 3 & 50 & 3 & 50 & 6 & 100 \\
\hline 2. & $\begin{array}{l}\text { Growing students' activeness to express } \\
\text { their ideas or others }\end{array}$ & 6 & 100 & 0 & 0 & 6 & 100 \\
\hline 3. & $\begin{array}{l}\text { Growing students' activeness to express } \\
\text { their ideas or others }\end{array}$ & 6 & 100 & 0 & 0 & 6 & 100 \\
\hline 4. & $\begin{array}{l}\text { Grow student activity to demonstrate or } \\
\text { present the results of group } 1 \text { discussions }\end{array}$ & 1 & 16,7 & 5 & 83,3 & 6 & 100 \\
\hline 5. & $\begin{array}{l}\text { Growing students' activeness to do } \\
\text { discussions }\end{array}$ & 5 & 83,3 & 1 & 16,7 & 6 & 100 \\
\hline & Total & 21 & $70 \%$ & 9 & $30 \%$ & 30 & 100 \\
\hline
\end{tabular}

The table above shows that; The first is growing student activity to ask questions, which indicates that 3 of the six teachers observed or $50 \%$ of teachers can foster student activity to ask questions. Both teachers can foster student activeness to express their ideas or others, showing 6 of the six teachers observed or $100 \%$ of teachers able to promote student activity to voice their opinions or others. The three teachers were able to grow concentration/students not sleepy and daydreaming, showing that 6 of the six teachers observed or $100 \%$ of teachers were able to develop concentration/students were not tired and daydreaming. Fourth Growing students' activeness to demonstrate or present the results of group discussions, showing 1 of 6 teachers observed or $16.7 \%$ of teachers were able to foster student activity to demonstrate or present the results of group discussions. Fifth Growing students' activeness to hold discussions, showing that 5 of the six teachers observed or $83.3 \%$ of teachers were able to foster student 
activity to conduct studies. So that in this variable indicates the teacher can grow student activeness with a percentage of $70 \%$.

Data about how teachers can foster student activity from the results of observations on five indicators of student activity including; 1) foster student activity to ask questions, 2) foster student activeness to express their ideas, 3) grow student concentration, 4) foster activeness to demonstrate and present, and 5) foster student activity for discussion. Of the five indicators mentioned above, it can be said that thematic learning can foster student activity in education has not been answered in full. From the results of the study only obtained an average of $70 \%$. In the sense that the teacher has not been fully able to establish student activity in the classroom, in other words, the teacher has not been maximized in fostering student activity in learning. Thus, it is suggested that the teachers in the future further enhance their ability to grow student activity in knowledge.

\subsection{The Teacher Can Apply the Principle of Learning While Playing}

Table 4. The Teacher can Apply the Principle of Learning While Playing

\begin{tabular}{|c|c|c|c|c|c|c|c|}
\hline \multirow[t]{3}{*}{ No } & \multirow[t]{3}{*}{ Statement } & \multicolumn{4}{|c|}{ Total } & \multicolumn{2}{|c|}{ Total } \\
\hline & & \multicolumn{2}{|c|}{ Yes } & \multicolumn{2}{|c|}{ No } & \multirow[t]{2}{*}{$\mathbf{N}$} & \multirow[t]{2}{*}{$\mathbf{P}$} \\
\hline & & $\mathbf{F}$ & $\%$ & $\mathbf{F}$ & $\%$ & & \\
\hline 1. & Students dare to try and be different & 6 & 100 & 0 & 0 & 6 & 100 \\
\hline 2. & $\begin{array}{l}\text { Students are not afraid of being ridiculed by } \\
\text { their abilities }\end{array}$ & 6 & 100 & 0 & 0 & 6 & 100 \\
\hline 3. & Students are motivated in learning & 6 & 100 & 0 & 0 & 6 & 100 \\
\hline 4. & $\begin{array}{l}\text { The class atmosphere is relaxed and not } \\
\text { stressful }\end{array}$ & 6 & 100 & 0 & 0 & 6 & 100 \\
\hline & Total & 24 & 100 & 0 & 0 & 24 & 100 \\
\hline
\end{tabular}

The table above shows that; First, the students dare to try and do, which shows 6 of the six teachers observed or $100 \%$ of students dare to try and do. Both students were not afraid of being ridiculed by their abilities, showing 6 of the six teachers observed or $100 \%$ of students not scared of being ridiculed by their skills. Third Students are motivated in learning, showing 6 of the six teachers observed or $100 \%$ of students motivated in education. The four classes are relaxed and not tense, showing 6 of the six teachers observed or $100 \%$ comfortable and not tight. In the variable teacher can apply the principle of learning while playing at a percentage of $100 \%$, meaning that all teachers can implement it.

Data on how teachers can apply the principle of learning while playing from the results of observations on four indicators of the law of learning while performing include; 1) Students dare to try and do, 2) Students are not afraid of being ridiculed by their abilities, 3) Students are motivated in learning, and 4) The class atmosphere is relaxed and not tense. From the results of the study it can be said that according to the theory stated earlier, thematic learning conducted in the Madrasah IbtidaiyahNegeriPekanbaru can apply the principle of education while playing with a percentage of $100 \%$. 


\subsection{The Teacher Gives Clear Instructions to the Responsibilities of Individuals and Groups Against Each Task That Demands the existence of Group Cooperation}

Table 5. The Teacher Gives Clear Instructions to the Responsibilities of Individuals and Groups Against Each Task That Demands the presence of Group Cooperation

\begin{tabular}{|c|c|c|c|c|c|c|c|}
\hline \multirow[t]{3}{*}{ No } & \multirow[t]{3}{*}{ Statement } & \multicolumn{4}{|c|}{ Total } & \multicolumn{2}{|c|}{ Total } \\
\hline & & \multicolumn{2}{|c|}{ Yes } & \multicolumn{2}{|c|}{ No } & \multirow[t]{2}{*}{$\mathbf{N}$} & \multirow[t]{2}{*}{$\mathbf{P}$} \\
\hline & & $\mathbf{F}$ & $\%$ & $\mathbf{F}$ & $\%$ & & \\
\hline 1. & $\begin{array}{l}\text { The existence of clear individual } \\
\text { assignments }\end{array}$ & 0 & 0 & 6 & 100 & 6 & 100 \\
\hline 2. & There is a collaboration between groups & 0 & 0 & 6 & 100 & 6 & 100 \\
\hline & Total & 0 & 0 & 12 & 100 & 12 & 100 \\
\hline
\end{tabular}

The table above shows as follows; First, there is a clear assignment of individual tasks, which shows 0 out of 6 teachers observed or $0 \%$ giving individual assignments. Second is the collaboration between groups, showing 0 out of 6 teachers noted or $0 \%$ collaboration between groups. Thus, there is no $0 \%$ teacher in applying to learn by giving clear instructions to the responsibilities of individuals and groups towards each task that demands group collaboration.

Data on how teachers give clear instructions on individual and group responsibilities in applying group learning include; 1) The teacher provides clear individual assignments, 2) and there is collaboration in groups. The results of the study show that the teacher does not give clear instructions on individual and group responsibilities for each task that demands group collaboration with a percentage of $0 \%$ meaning that there are no teachers who apply thematic learning by forming students in several groups. When referring to the RPP documentation made by the teacher, when viewed from the learning steps in the RPP, the learning carried out by the teacher is by the steps that have been designed. However, when referred to the method used in the RPP two teachers apply the discussion method in their RPP. The theoretical approach of discussion requires group collaboration, not a debate if only done alone.

\subsection{The teacher can explain concepts to students through direct experience}

Table 6.Explain Concepts to Students Through Direct Experience

\begin{tabular}{|c|c|c|c|c|c|c|c|}
\hline \multirow[t]{3}{*}{ No } & \multirow{3}{*}{ Statement } & \multicolumn{4}{|c|}{ Total } & \multicolumn{2}{|c|}{ Total } \\
\hline & & \multicolumn{2}{|c|}{ Yes } & \multicolumn{2}{|c|}{ No } & \multirow[t]{2}{*}{$\mathbf{N}$} & \multirow[t]{2}{*}{$\mathbf{P}$} \\
\hline & & $\mathbf{F}$ & $\%$ & $\mathbf{F}$ & $\%$ & & \\
\hline 1. & $\begin{array}{l}\text { The teacher can explain concepts to students } \\
\text { through direct experience }\end{array}$ & 5 & 83.3 & 1 & 16.7 & 6 & 100 \\
\hline & Total & 5 & 83.3 & 1 & 16.7 & 12 & 100 \\
\hline
\end{tabular}

In the table above shows that the teacher can explain the concept of the material explained through direct experience with a percentage of $83.3 \%$ or 5 of the six teachers observed. One characteristic of thematic learning is that learning is carried out through direct experience "learning by doing." In thematic learning, students are invited to understand the concept through activities that physically do them. In the table discussed above shows that the teacher 
can explain the idea of the material described through direct experience with a percentage of $83.3 \%$. Teachers can teach concepts to students through direct experience

\subsection{As long as learning takes place the separation of subjects is not very clear}

Table 7. During Learning the Separation of Subjects is not Clear

\begin{tabular}{|c|c|c|c|c|c|c|c|}
\hline \multirow[t]{3}{*}{ No } & \multirow[t]{3}{*}{ Statement } & \multicolumn{4}{|c|}{ Total } & \multicolumn{2}{|c|}{ Total } \\
\hline & & \multicolumn{2}{|c|}{ Yes } & \multicolumn{2}{|c|}{ No } & \multirow[t]{2}{*}{$\mathbf{N}$} & \multirow[t]{2}{*}{$\mathbf{P}$} \\
\hline & & $\mathbf{F}$ & $\%$ & $\mathbf{F}$ & $\%$ & & \\
\hline 1. & $\begin{array}{l}\text { During learning the separation of subjects is } \\
\text { not very clear }\end{array}$ & 3 & 50 & 3 & 50 & 6 & 100 \\
\hline & Total & 3 & 50 & 3 & 50 & 12 & 100 \\
\hline
\end{tabular}

In the table above shows that the teacher's ability in thematic learning by paying attention to during the teaching of the separation of subjects is not very clear at only $50 \%$ or 3 of 6 teachers. Thematic learning is learning that combines several topics that bind them in a theme by paying attention to several indicators that will be taught. Although there are several subjects that will be taught in the process, the teacher must be able to cover the separation of the items in other words as long as learning takes place the separation of subjects is not so bright when the teacher applies thematic knowledge. In the table as before, it shows that the teacher's ability in thematic learning by paying attention to during the teaching of the separation of subjects is not very clear at only $50 \%$

\subsection{The teacher Uses Media Maximally}

Table 8. Utilization of Learning Media

\begin{tabular}{|c|c|c|c|c|c|c|c|}
\hline \multirow[t]{3}{*}{ No } & \multirow[t]{3}{*}{ Statement } & \multicolumn{4}{|c|}{ Total } & \multicolumn{2}{|c|}{ Total } \\
\hline & & \multicolumn{2}{|c|}{ Yes } & \multicolumn{2}{|c|}{ No } & \multirow[t]{2}{*}{$\mathbf{N}$} & \multirow[t]{2}{*}{$\mathbf{P}$} \\
\hline & & $\mathbf{F}$ & $\%$ & $\mathbf{F}$ & $\%$ & & \\
\hline 1. & The teacher uses the media appropriately & 2 & 33.3 & 4 & 66.7 & 6 & 100 \\
\hline 2. & $\begin{array}{l}\text { Media preparation does not take time for } \\
\text { the teaching and learning process }\end{array}$ & 3 & 50 & 3 & 50 & 6 & 100 \\
\hline 3. & $\begin{array}{l}\text { The message conveyed through the media } \\
\text { is interesting and clear mount }\end{array}$ & 2 & 33.3 & 4 & 66.7 & 6 & 100 \\
\hline & Total & 7 & 39 & 11 & 61 & 18 & 100 \\
\hline
\end{tabular}

The table above shows that; first. The teacher used the media appropriately, only two teachers $(33.3 \%)$ from 6 teachers. Second, the use of press does not take up student learning time obtained three teachers $(50 \%)$ of the six teachers have been able to utilize the maximum time in the use of media so that it does not take up student learning time. Third, the message conveyed through the media was interesting and clearly showed that only two teachers $(33.3 \%)$ of the six teachers were able to create media that produced inspiring messages and clearly. Of the three indicators, only $39 \%$ of teachers can utilize the media to the fullest.

Media utilization in learning acts as an intermediary for channeling messages from teachers to students. Media also has benefits including making notes more exciting and interactive. Thus, some experts consider the media to be very urgent in its existence in every 
learning including thematic learning. The maximum use of media in thematic education can be seen in the table above, showing that the use of media by teachers in thematic learning is only $39 \%$ of the three indicators of maximum media use.

\subsection{The teacher utilizes time and energy appropriately}

Table 9. Appropriate Time and Energy Utilization

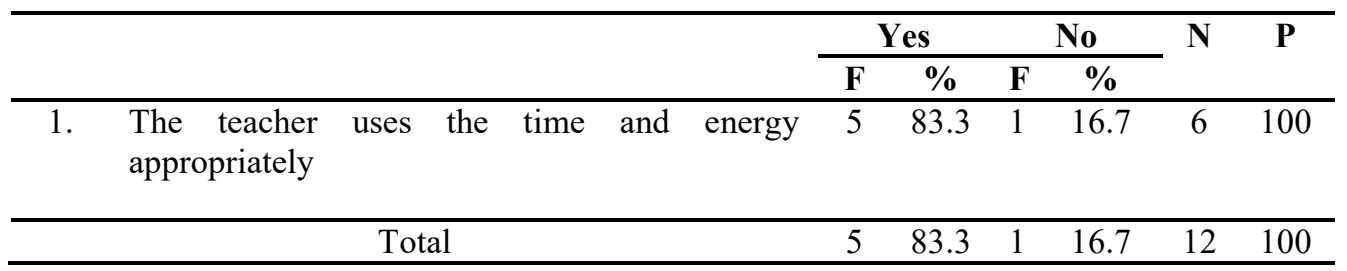

The table above shows that the proper use of time and energy is right, this is obtained by five teachers $(80.3 \%)$ of the six teachers who have utilized their time and energy appropriately. In each learning time allocation has been set for each lesson hour (JPL), one lesson is 35 minutes. From the results of the study, it was obtained data that the proper use of time and energy was right, this is obtained by five teachers $(80.3 \%)$ of the six teachers who had utilized their time and energy appropriately.3) Teachers can achieve high-quality learning outcomes based on the competencies that are the goalTable. 22Teachers can produce high-quality learning outcomes based on the skills that are the goal

\subsection{Teachers Can Achieve High-Quality Learning Outcomes Based on the Competencies that are the Goal}

Table 10. Teachers can Achieve High-Quality Learning Outcomes

\begin{tabular}{lllccccc}
\hline \multirow{2}{*}{ No } & Statement & \multicolumn{3}{c}{ Total } & \multicolumn{3}{c}{ Total } \\
\cline { 3 - 6 } & & \multicolumn{2}{c}{ Yes } & \multicolumn{2}{c}{ No } & N & P \\
\cline { 3 - 6 } & No student cheated during the test & 3 & 50 & 3 & 50 & & 100 \\
\hline 1 & $\begin{array}{l}\text { There are no remedial students, the value of } \\
\text { learning outcomes is above / equivalent } \\
\text { Total }\end{array}$ & 4 & 66.7 & 2 & 33.3 & 6 & 100 \\
\hline 2 & 7 & 66.6 & 5 & 33.4 & 12 & 100 \\
\hline
\end{tabular}

Data on learning outcomes above shows that the quality of learning outcomes reaches $66.6 \%$. From the two indicators, the quality of learning outcomes was obtained. First, there were no students who cheated during the test, from the observations of 6 teachers who taught in 6 classes, in 3 levels no students were cheating, while in the other two classes students were cheating and one other type was not tested. The two students who were not remedial found a percentage of $83.3 \%$.

Data on learning outcomes above shows that the quality of learning outcomes reaches $66.6 \%$. From the two indicators, the quality of learning outcomes is obtained. First, there were no students who cheated during the test, from the observations of 6 teachers who taught in 6 classes, in 3 levels no students were cheating, whereas in the other two classes students 
cheated and one other class did not teachers did not post test. The two students who were not remedial found a percentage of $83.3 \%$.

\section{Conclusion}

The effectiveness of the implementation of thematic learning in MIN in Pekanbaru is classified as very active with a percentage of $84.1 \%$. These results are representative of several indicators carried out by the teacher, namely: 1) Making RPP according to the steps of thematic learning, 2) Non-authoritarian teachers, 3) Teachers can foster student activity, 4) Apply the principle of education while playing, 5) Explain concepts through direct experience, 6) Separation of subjects is not clear, 7) using media, 8) Utilizing time and energy appropriately, 8) Achieving high quality results.

Pembelajaraan tematik di sd merupakan terapan dari pembelajaran terpadu

\section{References}

[1] B. Warsita, Teknologi Pembelajaran: Landasan dan Aplikasinya. Jakarta: Rineka Cipta, 2008.

[2] D. I. Kelas and A. Sekolah, "Pengembangan model pembelajaran tematik di kelas awal sekolah dasar," 1991.

[3] D. P. Nasional, D. Jenderal, P. Dasar, and D. A. N. Menengah, "Pembelajaraan tematik di sd merupakan terapan dari pembelajaran terpadu," Yogjakarta, 2004.

[4] A. H. Hernawan and N. Resmini, "Konsep Dasar dan Model-model Pembelajaran Terpadu," 2010.

[5] N. N. Sukerti, A. A. I. N. Marhaeni, and N. K. Suarni, "Pengaruh Pembelajaran Tematik Terpadu melalui Pendekatan Saintifik terhadap Minat Belajar dan Hasil Belajar Siswa Kelas IV SD Negeri 2 Tibubeneng Kuta Utara," PENDASI J. Pendidik. Dasar Indones., vol. 4, no. 1, 2015.

[6] K. S. Diputra, "Pengembangan Multimedia Pembelajaran Tematik Integratif Untuk Siswa Kelas IV Sekolah Dasar," JPI (Jurnal Pendidik. Indones., vol. 5, no. 2, p. 830, Jan. 2017.

[7] Mulyadin, "Implementasi Kebijakan Pembelajaran Tematik Terpadu Kurikulum 2013 di SDN Kauman 1 Malang dan SD Muhammadiyah 1 Malang," J. Pendidik. Edutama, vol. 3, no. 2, pp. 31-48, 2016.

[8] A. Suharsimi, "Summary for Policymakers," in Climate Change 2013 - The Physical Science Basis, Intergovernmental Panel on Climate Change, Ed. Cambridge: Cambridge University Press, 2010, pp. 1-30. 